\title{
Connotation Interpretation on Modern Value of National Dance
}

\author{
Xiaojie Wang ${ }^{1, a}$, Chi Zhang, \\ ${ }^{1}$ College of Art and Communication, Bohai University, Jinzhou, 121013, China \\ ${ }^{2}$ School of Education and Sports, Bohai University, Jinzhou, 121013, China \\ a1019813588@qq.com, b378290420@qq.com
}

Keywords: national dance; modern value; connotation interpretation

\begin{abstract}
The use of music, dance rhythm and body language in national dance not only reflects the expression of the dancer's face and the implication of dance, but also the artistic connotation of dance. In the course of historical development, different ethnic groups have created different national dances, and different ethnic dances show different national cultural customs. National dance is inseparable from national culture. The unique charm of national dance is precisely because of its cultural value. National dance absorbs the essence of national culture. It is both vivid and rich, and it is not only the part of national culture, but also the character of national culture. Ethnic dance has modern values in eight aspects: cultural value, aesthetic value, entertainment value, communicative value, educational value, commercial value, international value and artistic value.
\end{abstract}

\section{Introduction}

National dance refers to the production and spread among the people, the style is relatively stable, with self-entertainment as the main function, restricts to folk culture, it is a form of impromptu performance dance. Folk dance from different regions, countries and nationalities are influenced by factors such as living environment, customs, lifestyle, national character, cultural traditions and religious beliefs, as well as physiological conditions such as the age and sex of the performers. There are very obvious differences in style. Folk dances are characterized by simplicity, variety, rich content and vivid images. They have always been an indispensable source of classical dance, folk dance, court dance and professional dance creation. National dance is a symbol of a nation, a soul of a nation and even a country. National dance requires artists to re-create the high degree, from the folks to the folks.

In the long river of Chinese history, various ethnic groups have formed the dance culture with unique national characteristics. The reason why the national dance culture is loved by the majority of the people is because it expresses people's demands, the desire and pursuit of a better life, and people's physical and mental pleasure in the national dance culture. But the world is constantly evolving and people's needs are constantly changing. If the national dance culture wants to develop better, it must recognize people's needs and continue to make progress to meet people's needs. With national dance as a carrier, it has fully played its artistic role. However, while the national dance culture continues to dig deeper, it also needs to pay attention to advancing with the times, constantly innovating, and developing better in the ever-changing world. Therefore, in modern society, to inherit and carry forward the national dance culture, we must excavate the modern value of national dance, let the national dance culture go deeper into the people's hearts, and promote the national dance culture to go out, making the outstanding national culture shine.

\section{Cultural Value of National Dance}

The artistic charm and aesthetic value of national dance are incomparable to modern dance, and national dance is inseparable from national culture. National dance has the unique charm, precisely because of the cultural value they display. National dance absorbs the essence of national culture, and presents the essence of national culture in front of people in the form of songs and dances. It is 
both vivid and rich, and it is rich in connotation. It is not only a part of national culture, but also reflects the character of national culture. National culture is not only the wisdom condensed by people's lives, but also the spiritual sustenance of a nation's survival and development. Different nationalities have different cultures, and thus the styles of dances of each ethnic group are also different. National dance originates from the life and customs of ethnic areas, and are related to the local geographical environment and life. Different dance movements show different national cultural connotations. In modern society, national dance should be based on the combination of tradition and modernity, follow the essence of integration, and adopt cultural development to treat cultural inheritance. It must have the ideology of modern and traditional organic integration. This is also the national dance in modern society, and is the main idea of development. It should be noted that in the process of development, we must master the scale of adjustment and integration, adhere to the national characteristics, style and value, and finally present the modern national dance works, fully reflecting people's breakthroughs in tradition, the organic use of innovation and combining and demonstrating the new concept of national dance culture, effectively expanding and extending the cultural spirit, thus forming a modern art work with deeper ideological concepts and cultural heritage.

\section{Aesthetic Value of National Dance}

The history of national dance is profound and it is also an aesthetic art. From this, we can appreciate the most primitive state of aesthetic feelings and have a very strong modern aesthetic value. First, the form of beauty creates unfamiliar effect. In addition to its strong national characteristics, national dance also contains ethnic origins and historical concepts, and aesthetic concepts are also reflected in dance. National dance respects the nation and can create a unfamiliar effect in the modern aesthetic system. The national dance has carried out the artistic expression of the epic. It needs to process the original things. The use of the symbolic techniques is more common. It originates from the national life, but transcends the national life and conveys the theme from the artistic perspective. Second, transcend the pursuit of skills to explore the aesthetic theme. Through the continuity of music and the integrity of the plot, enriching the movement connotation of national dance can not only play the role of edifying the soul, but also can record the national life. The rich connotation of national dance can achieve a better aesthetic effect. National dance emphasizes not the skill, but also pays more attention to excavating the aesthetic theme, which has important enlightenment to modern art. Third, with the epic performance to create a sense of history. National dance represents the national life and culture from the artistic point of view, making the national life more rich and intense. When the audience appreciates the national dance, they not only have the pleasure of the soul, but also the process of creating history in all members of the nation, combining different aesthetic feelings and shaping new things while aesthetic experience.

\section{Entertaining Value of National Dance}

Dance reflects people's life and is also higher than people's life. Due to the backwardness of economic development in ethnic areas, other cultural and entertainment methods are limited. National dance has become an important part of cultural entertainment. Leisure and entertainment is the most prominent feature of national dance. People to dance mainly for the sake of entertainment, leaving the fundamental characteristics of entertainment, the national dance left the people. With its unique form of performance, dance relieves people's stress in work and study and achieves entertainment. As a unique way of entertainment, dancers feel the connotation of dance while performing, and subtly blend their inner feelings and dances to achieve their own emotional relief and enjoy the pleasure of self-entertainment. The national dance comes from people's "instinctive impulse" and "self-expression" consciousness. It is an artistic expression of the people's self-entertainment and is the most sincere emotion of people's hearts. The entertainment function of the national dance is the performance form of the dancers through the dance, giving the viewer a sense of pleasure and visual enjoyment, so that they can be spiritually satisfied and comforted. 
Because the movements of folk dances are relatively simple and refined, they are easy to be mastered by the people. Not only can they release the pressure, but they can also harvest happiness and feel the history of Chinese culture. With the improvement of people's living standard and the further development of national dances, people's requirements for national dances are constantly improving, not only paying attention to their connotations, but also paying attention to improving their ornamental value. The appreciation of national dance is also gradually strengthened.

\section{Communication Value of National Dance}

With economic and social development, people are increasingly focusing on the status and role of culture in a country. The "soft power" advocated now includes culturally-oriented "soft power". As one of the cultural "soft power", national dance promotes the exchange of dance culture between Chinese and foreign ethnic groups with its unique status and value. The ethnic ethnic groups living in the border areas are important passages for the Chinese nation's foreign economic and cultural exchanges and play a unique role in the exchange and dissemination of dance culture. The Silk Road, which is well-known both at home and abroad and across Asia and Europe, has played an important role in promoting the exchange and development of the East and West economy and culture. As the "mother of art", dance has highlighted its unique status and role in the cultural and artistic exchanges between China and ASEAN. Through dance performances, exchanges and cooperation between different ethnic groups and art have been realized, and the understanding and trust of ASEAN countries and China and the rest of the world have been enhanced. At the annual "China-ASEAN" Expo, cultural and artistic exchanges have played a huge role in promoting the exchange of national dance as a major form, which has enhanced the traditional friendship between China and ASEAN countries. The activities of the various nationalities in the motherland are exchanged. The people also use the traditional form of national dance to express the character temperament and emotional life of different ethnic groups with human body movements, to achieve exchanges between the nation and the nation, and to promote ethnic exchanges and integration. On the road of national unity, national harmony and national development, it played an irreplaceable role, fully reflecting the great significance of national dance to the construction of society.

\section{Educational Value of National Dance}

As a kind of teaching resource, national dance is a kind of teaching system and has important educational value. It is highlighted in the following aspects: first, it encourages students' national morale. Many national dance was created because of the need of war, reflecting the scene of war or the joy of victory. They have the characteristics of vivid story, rich content, distinctive characters and complete storylines, which inspire people to oppose oppression and struggle. Second, deepen students' recognition of national culture. Different national lifestyles, historical spread, customs and religious beliefs have produced national dance with different styles. Through performances and dances, students learn about history, memory history, and heritage, and enhance national sense of history, self-respect and self-confidence. Third, cultivate the students' sentiment. The most original meaning of dance is self-entertainment and venting feelings. The national dance expresses the feelings that ordinary people can understand and accept, and can pulsate the heartstrings of ordinary people. In the artistic activities of national dance, people directly participate in, express emotions, be satisfied in spirit, achieve self-entertainment, achieve psychological adjustment, supplement and communication, and achieve a new balance of mentality. Fourth, it is conducive to the cultivation of students' personality. The national dance is mostly based on the theme of evil, good fortune, righteousness and evil, respect for the elderly, unity and mutual assistance, and diligence and self-improvement. The vivid dance art image and wonderful artistic performance reflect the wishes, ideals and good life of the people. The pursuit can enable students to feel a positive passion and have a positive educational function. 


\section{Commercial Value of National Dance}

Commercial value refers to the economic value of things in production, consumption, and trading, and is usually expressed and measured in units of money. The rich cultural heritage of national dance brings potential commercial value to the market. At the same time that the material is satisfied, people begin to pursue spiritual enjoyment. More and more people participate in the exercise and learning of dance, which promotes the development of the dance industry and plays a role in promoting the art market of dance. Dance has evolved from an art to an industry, and it needs to combine its artistic value with market value. While appreciating the value of dance art, it explores its artistic connotation and marketability and creates considerable commercial value. Contemporary national art, including national dance, is not a single, stable and closed cultural context in the past, but a kind of globalization discourse, mass consumer culture discourse, national traditional cultural discourse. The industrialization of national dance is not only to create commercial interests. In the process of commercialization, the innovation of national dance does not lose the root of the nation, and does not weaken the style of the nation and the soul of the nation. National dance as a cultural language, the development in the cultural industry also plays a positive role in the inheritance and continuation of the national dance art. In the marketing market operation, national dance aims at maximizing business benefits, rationally planning development routes, perfecting the market operation system, cultivating the aesthetic intuition of the whole people, deepening the spiritual life of the whole people and creating a more exciting spiritual world.

\section{International Value of National Dance}

With the development of the international economy, culture, as the soft power of the country, makes an important contribution to the international status of a country. Cultural strength has gradually become an important indicator for measuring the core competitiveness of the country. As an important part of the national culture, national dance not only reflects the cultural heritage of the Chinese nation, but also shows the spiritual outlook of the Chinese nation. Many national dance show the spirit of the Chinese people's love of labor and hard work. As China opens up to the outside world, more and more foreigners come to China to carry out cultural tourism projects in ethnic group areas. National dance is an important part of it. By performing national dance for foreign guests, on the one hand, it shows the local ethnic customs. On the other hand, foreign guests are also able to understand the Chinese national culture. China also holds folk song festivals in ethnic group areas. Through national dances, it displays national traditional culture on the one hand and promotes Chinese folk dance to the world market. In China, there are many programs and song and dance troupes to the world, touring in countries around the world, to show the charm of Chinese folk dance to the international community, and to show the characteristics of the Chinese nation. To carry out foreign dance art exchanges, show and spread the Chinese national dance art to the world, and introduce the international excellent dance culture to China, thus promoting the important purpose of China's socialism. In the process of promoting national dance, we need to keep pace with the times, grasp the pulse of the times, innovate and beautiful national dance art, promote the spread and inheritance of national dance, and enhance the artistic charm and international influence of national dance.

\section{Artistic Value of National Dance}

The artistic value of national dance is reflected in style, rhythm, traits and themes. Due to different living environments and living habits, various ethnic groups have formed distinctive dance styles. Because of the different personality characteristics and emotional colors, national dance has both rustic and unrestrained style characteristics. The rhythm of the national dance is beautiful. With its colorful dance performance art, it combines the basic rhythm and the rhythm of action to form a unique appreciation value. The artistic traits of dance are characterized by distinctive 
features, bright rhythms and simple folk customs. In ancient colors, the spirit of the national spirit is enthusiastically and unrestrained. The artistic characteristics of national dance expresses the ardent desire for a better life of the country, nation, nature and humanity through thematic expressions. The artistic value of national dance is also reflected in the free and lively theme style, the special costumes of various national dance, and the national song. In the scene of singing and dancing, the lively life content is not only easy to understand, but also with the help of props. Enhance the artistry of dance culture. The national dance also has the original ecological artistic value. It has not been specially carved. It exists in the folk original and exudes a local performance form, including the original ecological singing method, the original ecological dance and the original ecological singer, etc., which reflects the strong original ecology. Culture and life. The background of the birth of the national dance is not only in terms of regional culture, but also in the religious beliefs and cultural traditions among the various ethnic groups, so that the artistic value is fully displayed.

\section{Acknowledgement}

This work is supported by social science fund project of Liaoning province (L17CMZ002): Innovation measures on promote the outstanding national dance culture going out under the "One Belt and One Road" strategy.

\section{References}

[1] M. X. Zou, "On the Modern Value of National Dance," Artistic Ocean, vol. 63, no. 7, pp. 132-133, 2013.

[2] Y. Ping, S. Y. Chen, "On the National Cultural Characteristics and Modern Aesthetic Value of National Dance," China National Exhibition, vol. 22, no. 5, pp. 143-144, 2017.

[3] H. Liu, "The Value and Spread of National Dance in Modern Society," Art Evaluation, vol. 2, no. 18, pp. 62-64, 2016.

[4] Q. Guo, "Research on Chinese National Dance Creation under the Influence of Dance Marketization," https://www.xzbu.com/4/view-6326888.htm, 2018-10-2.

[5] Thesis alliance, "Seeing the Nationality of National Dance and Its Artistic Value," http://www.lwlm.com/yishulunwen/201410/746784.htm, 2018-10-2.

[6] N. Liu, "Research on Aesthetic Value and Cultural Inheritance of National Dance," Journal of Heihe University, vol. 9, no. 1, pp. 197-198, 2018.

[7] M. X. Li, L. Yu, "The Aesthetic Value and Appreciation of Chinese National Dance," Big stage, vol. 56, no. 7, pp. 92-93, 2013.

[8] Z. Y. Jiang, "Talking about the commercial value of the dance industry," Song of the Yellow River, vol. 44, no. 4, pp. 78-79, 2013. 